\title{
PLYOMETRIC TRAINING IMPROVES SWIMMING PERFORMANCE IN RECREATIONALLY-TRAINED SWIMMERS
}

\author{
O TREINAMENTO PLIOMÉTRICO MELHORA O DESEMPENHO DE NADADORES RECREATIVOS
}

inal ARTICLE

EL ENTRENAMIENTO PLIOMÉTRICO MEJORA EL DESEMPEÑO DENADADORES RECREATIVOS

Original Article

ARTIGO ORIGINAL Artículo Original

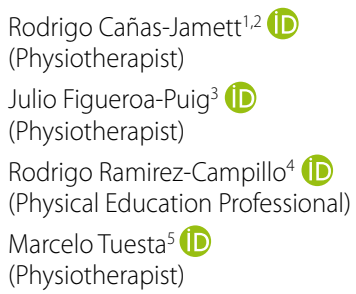

1. Universidad Andres Bello, Faculty of Life Sciences, Physiology Laboratory, Department of Biological Sciences, Viña del Mar, Chile.

2. Integrative Physiology Unit, Leisure, Sport and Health Sciences Laboratory CEDS, Viña del Mar, Chile.

3. Universidad Mayor, Facultad de Medicina, Escuela de Kinesiología, Santiago, Chile.

4. Universidad de Los Lagos, Laboratory of Human Performance. Research Nucleus in Health, Physical Activity and Sport. Quality of Life and Wellness Research Group. Department of Physical Activity Sciences, Osorno, Chile. 5. Universidad Andres Bello, Faculty of Rehabilitation Sciences, School of Kinesiology, Viña del Mar, Chile.

\section{Correspondence:}

Rodrigo Cañas-Jamett,

Physiology Laboratory,

Department of Biological

Sciences, Faculty of Life Sciences,

Universidad Andres Bello.

Quillota 980, 2531015, Viña del Mar,

Chile.rcanas@unab.cl

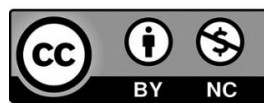

\begin{abstract}
Introduction: Plyometric training significantly improves strength performance, including in aquatic sports. Objective: To compare changes in thigh girth, hamstring flexibility, squat jump height, and 200m swimming trial time induced by plyometric training in recreationally-trained swimmers. Methods: Eighteen recreationally-trained male swimmers (age $=18$-20 years) were randomly divided into a plyometric training group (PTG) and a control group (CG). All the swimmers completed a six-week speed swimming training plan. In the PTG only, the last 15 min of each session was replaced with plyometric exercises. The physical characteristics and the thigh girth were measured before and after the six weeks of training. In addition, sit-and-reach flexibility and squat jump tests were conducted, as well as a 200m swimming trial. Results: Two-way ANOVA with post-hoc analysis revealed an increase in sit-and-reach flexibility (PRE: $4.5 \pm 5.3 \mathrm{~cm}$; POST: $10.9 \pm 5.9 \mathrm{~cm}, \mathrm{p}<0.01$ ) and squat jump height (PRE: $24.9 \pm 3.7 \mathrm{~cm}$; POST: $28.3 \pm 4.2 \mathrm{~cm}, p<0.01$ ) and a decrease in 200m-swimming time (PRE: $220 \pm 26.5 \mathrm{sec}$; POST: $204 \pm 24.4 \mathrm{sec}, \mathrm{p}<0.01$ ) for the PTG only. Comparing the absolute changes (post-pre) between the groups by the Student's t-test, the PTG showed a greater increase in distance reached in the sit-and-reach flexibility (PTG: $6.34 \pm 0.6 \mathrm{~cm}$ vs. CG: $2.4 \pm 1.2 \mathrm{~cm}, \mathrm{p}<0.01$ ) and squat jump height (PTG: $3.4 \pm 0.7 \mathrm{~cm}$ vs. CG: $0.7 \pm 0.3 \mathrm{~cm}, p<0.01$ ) than the CG. In addition, the $200 \mathrm{~m}$ swimming time decreased significantly more than in the CG (PTG: $-15.1 \pm 2.4$ sec vs. CG: $-0.8 \pm 2.7 \mathrm{sec}, \mathrm{p}<0.01)$. Conclusion: Plyometric training improves jump height, flexibility, and $200 \mathrm{~m}$ swimming performance in recreationally-trained adult swimmers. Level of Evidence Il; Lesser quality $R C T$.
\end{abstract}

Keywords: Swimming; Plyometric exercise; Sports performance; Stretch-shortening exercise.

\section{RESUMO}

Introdução: O treinamento pliométrico melhora significativamente o desempenho de força, inclusive em esportes aquáticos. Objetivo: Comparar alterações da circunferência da coxa, flexibilidade dos isquiotibiais, altura do salto em agachamento e tempo de prova de natação de 200 metros depois de treinamento pliométrico em nadadores recreativos. Métodos: Dezoito nadadores recreativos do sexo masculino (idade $=18$ a 20 anos) foram divididos randomicamente em um grupo de treinamento pliométrico (GP) ou controle (GC). Todos realizaram um plano de treinamento de natação em velocidade por seis semanas. Somente o GP substituiu os últimos 15 minutos de cada sessão por exercícios pliométricos. As características físicas e a circunferência da coxa foram medidas antes e depois das seis semanas de treinamento. Além disso, foram testados a flexibilidade (sentar e alcançar), o salto em agachamento e a prova de natação de 200 metros. Resultados: Um teste ANOVA de duas vias com análise post hoc revelou aumento da flexibilidade (PRÉ: 4,5 $\pm 5,3 \mathrm{~cm}$; PÓS: 10,9 $\pm 5,9 \mathrm{~cm}, p<0,01$ ) e altura do salto (PRÉ: $24,9 \pm 3,7 \mathrm{~cm}$; PÓS: $28,3 \pm 4,2 \mathrm{~cm}, p<0,01$ ), assim como diminuição do tempo de natação de 200 metros (PRÉ: $220 \pm 26,5$ s; PÓs: $204 \pm$ $24,4 s, p<0,01$ ), apenas para o GP. Ao comparar as alterações absolutas (pré-pós) entre os grupos com o teste $t$ de Student, o GP mostrou aumento maior da distância alcançada na flexibilidade no teste sentar e alcançar (GP: 6,34 \pm $0,6 \mathrm{~cm} ; G C: 2,4 \pm 1,2 \mathrm{~cm}, p<0,01$ ) e na altura do salto em agachamento (GP:3,4 $\pm 0,7 \mathrm{~cm} ; G C: 0,7 \pm 0,3 \mathrm{~cm}, p<0,01)$ do que o GC. Além disso, o tempo de natação de 200 metros diminuiu significativamente mais do que o GC (GP:-15,1 \pm $2,4$ s vs. GC: $-0,8 \pm 2,7 \mathrm{~s}, p<0,01)$. Conclusão: O treinamento pliométrico melhora a altura do salto em agachamento, a flexibilidade e o desempenho em 200 metros de natação em nadadores adultos recreativos. Nível de evidência ll; ECRC de menor qualidade.

Descritores: Natação; Exercício pliométrico; Desempenho esportivo; Exercício de alongamento e redução.

\section{RESUMEN}

Introducción: El entrenamiento pliométrico mejora significativamente el desempeño de fuerza, inclusive en deportes acuáticos. Objetivo: Comparar alteraciones de la circunferencia del muslo, flexibilidad de los isquiotibiales, la altura del salto en agachamiento y tiempo de prueba de natación de 200 metros luego de entrenamiento pliométrico en nadadores recreativos. Métodos: Dieciocho nadadores recreativos del sexo masculino (edad= 18 a 20 años) fueron divididos aleatoriamente en un grupo de entrenamiento pliométrico (GP) o control (GC). Todos realizaron un plan de entrenamiento de natación en velocidad de seis semanas. Solamente el GP sustituyó los últimos 15 minutos de cada sesión con ejercicios pliométricos. Las características físicas y circunferencia de muslo se midieron antes y después de las seis semanas de entrenamiento. Además, se evaluó la flexibilidad (sentar y alcanzar), salto en agachamiento y la prueba de natación de 200 metros. Resultados: Un test ANOVA de dos vías con análisis post hoc reveló aumento de 
Ia flexibilidad (PRE: 4,5 $\pm 5,3 \mathrm{~cm}$; POST: 10,9 $\pm 5,9 \mathrm{~cm}, p<0,01$ ) y altura de salto (PRE: $24,9 \pm 3,7 \mathrm{~cm}$; POST: $28,3 \pm 4,2 \mathrm{~cm}$, $p<0,01$ ), así como disminución del tiempo de natación de 200 metros (PRE: $220 \pm 260,5$ s POST: 204 $\pm 24,4 s, p<0.01$ ), solo para el GP. Al comparar las alteraciones absolutas (pre-post) entre los grupos con el test t de Student, el GP mostró mayor aumento de la distancia alcanzada en la flexibilidad en el test sentary alcanzar (GP:6,34 $0,6 \mathrm{~cm}$ vs. GC: 2,4 41,2 $\mathrm{cm}, p<0,01$ ) yen la altura del salto en agachamiento ( $G P: 3,4 \pm 0,7 \mathrm{~cm}$ vs. GC: $0,7 \pm 0,3 \mathrm{~cm}, p<0,01)$ que el GC. Además,

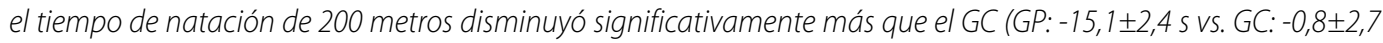
$s, p<0,01)$. Conclusión: El entrenamiento pliométrico mejora la altura del salto en agachamiento, la flexibilidad y el desempeño en 200m de natación en nadadores adultos recreativos. Nivel de Evidencia ll; ECRC de menor calidad.

Descriptores: Natación; Ejercicio pliométrico; Rendimiento deportivo; Ejercicio de estiramiento y acortamiento.

\section{INTRODUCTION}

It is recognised that strength training improves swimming performance. 'In a short-distance swimming race (i.e. 50-200m), the strength of the lower extremities takes greater preponderance than in a long-distance endurance challenge (i.e. $>1500 \mathrm{~m}$ ). ${ }^{2}$ In fact, it improves the power output during the jump from the starting block, ${ }^{3}$ dolphin kick, ${ }^{4}$ and flip turns, ${ }^{5}$ decreasing the race time. The common factor in these actions is explosiveness. A training mode that improves explosive strength and power output is plyometric training (PT). ${ }^{6}$ The PT is composed of repeated exercises as skips, jumps and hops. One advantage of PT in swimmers is that an increase in strength may not be associated with an increase in muscle mass of the thigh, which could increase drag force in the water and decrease speed while swimming. ${ }^{7}$ Furthermore, PT does not reduce flexibility in athletes, which prevents an increase in the probability of injury. Likewise greater flexibility has been related to better performance in swimmers. ${ }^{8}$

Current research into PT has demonstrated an improvement in jumping ability in activities including soccer, ${ }^{9}$ rowing ${ }_{1}^{10}$ handball, ${ }^{11}$ and hockey. ${ }^{12}$ This is no different in swimmers, but the scientific evidence is controversial and limited. Only two studies have shown that a short-period PT (for instance, a six-week or eight-week programme) may help to improve swimming performance. ${ }^{13,14}$ In contrast to this, Cossor et al. ${ }^{15}$ showed no benefits on swimming performance. All participants of these studies were competitive young swimmers. To date, the effects of PT on recreationally-trained adult swimmers are unknown. However, it is necessary to be cautious, as a high mechanical stimulus induced by plyometric exercise in lightly trained subjects could provoke a significant increase in muscle mass and decrease in flexibility, with consequent deleterious effects on performance. In fact, recently, a review indicated that some strength training could be questionable in low-level competitive swimmers. ${ }^{1}$ The aim of this study was to observe changes in the thigh girth, hamstring flexibility, squat jump height, and 200m swimming time trial in recreationally-trained adult swimmers after PT.

\section{MATERIALS AND METHODS}

\section{Participants}

Eighteen recreationally-trained adult swimmers participated in this study. General characteristics are summarised in Table 1. They had no previous experience with PT. Initially, an intentional sample of twenty swimmers with similar performance levels were recruited and randomly divided into a plyometric training group (PTG) and a control group (CG), each group with ten subjects. Two participants from the CG withdrew from the study due to injury not induced by training. Experimental protocols were performed in accordance with the ethical standards of the Helsinki declaration. Participants signed an informed consent form, approved by the responsible ethics committee from the Department of Physical Activity Sciences of the University of Los Lagos (ANXI07052018). The head coach of the swimming team also gave his approval for the study.
Table 1. General characteristics of recreationally-trained swimmers.

\begin{tabular}{c|c|c|c|c|c|c}
\hline Characteristics & \multicolumn{3}{c|}{$\begin{array}{c}\text { Control group } \\
(\mathbf{n}=10)\end{array}$} & \multicolumn{3}{c}{$\begin{array}{c}\text { Plyometric } \\
\text { group }(\mathbf{n = 8})\end{array}$} \\
\hline Age $(\mathrm{y})$ & 20.1 & \pm & 0.7 & 20.5 & \pm & 0.6 \\
\hline Height $(\mathrm{m})$ & 1.78 & \pm & 0.05 & 1.76 & \pm & 0.04 \\
\hline Body mass $(\mathrm{kg})$ & 75.4 & \pm & 5.4 & 74.8 & \pm & 4.9 \\
\hline Body mass index $\left(\mathrm{kg} \mathrm{m}^{-2}\right)$ & 23.8 & \pm & 1.7 & 24,1 & \pm & 1.6 \\
\hline Time experience in swimming $(\mathrm{y})$ & 2.7 & \pm & 0.9 & 2.8 & \pm & 0.75 \\
\hline $\begin{array}{l}\text { Value are given as mean } \pm \text { standard deviation. There was not significant differences between groups for basal } \\
\text { characteristics. }\end{array}$
\end{tabular}

The participants were carefully familiarised with the test procedures before the measurements were taken. Physical characteristics, thigh girth, hamstring flexibility, squat jump height, and 200m-swimming race time were measured before and after the six-week training programme. The CG carried out a speed swimming training programme, whereas the PTG replaced the final part of each session ( $15 \mathrm{~min}$ ) with plyometric exercises. All measurements were obtained between ten in the morning and 12 noon. Before the experimental training period, the measurements were obtained in the following order, physical characteristics, thigh girth, and jump height. The room was conditioned for temperature $\left(19-21^{\circ} \mathrm{C}\right)$ and relative humidity (60-70\%). Approximately $24 \mathrm{~h}$ later, the swimming race and hamstring flexibility tests were carried out in an indoor pool treated with chlorine. After the intervention period (six experimental weeks), the evaluations were again carried out in the same order, conditions, time of day and corresponding researcher. The researchers were blinded to group allocation. Participants were instructed to not consume any food, liquid and/or stimulating or diuretic substances prior to the experimental sessions.

Weight and height were measured with a stadiometer (BC-520, Tanita Corporation ${ }^{\circledR}$, Japan). Their body mass index was obtained by dividing body weight by height squared. In addition, time experience in swimming was collected.

\section{Thigh girth}

This variable was assessed one centimetre under the gluteal skinfold and perpendicular to the thigh axis. A non-extensible metallic tape of $0.5 \mathrm{~cm}$ width (Lufkin, Executive-Thinline ${ }^{\circledR}$, USA) was used to measure the thigh girth, while participants were standing with their feet shoulder width apart. Three measurements were carried out for each leg, in a counterbalance order (i.e., right, left). Since the difference between the first and second measurements were always $<0.5 \mathrm{~cm}$, the mean value between them was used for the analysis.

The sit-and-reach flexibility test was applied using a scale calibrated in centimetres, placed on the top surface of a sit-and-reach box (Baseline ${ }^{\circledR}$, USA). The test was performed by having participants sit on the floor, barefoot. The participants'feet were placed flat against the sit-and-reach box, separated by approximately $40 \mathrm{~cm}$. Then, they reached forward slowly toward their toes, as far as possible, while keeping their knees, arms, and 
fingers fully extended, with palms down. The participants had to place their right hand over the left, middle fingers level, holding the position of maximal reach for two seconds. The precision of the measurement was $0.5 \mathrm{~cm}$. Three maximal attempts were allowed and the best was used for analysis. Rest between trials was $\sim 30 \mathrm{sec}$. The flexibility test was applied $\sim 15$ min after the swimming test.

A squat jump was used to assess maximal vertical jump height performance. The test was performed using an electronic mat system (Ergojump, Globus $^{\circledR}$, Italy). The flight time (t) was used to estimate the height (h) of the rise of the body's centre of gravity $(\mathrm{g})$ during the vertical jump (i.e., $\mathrm{h}=\mathrm{gt}^{2} / 8$, where $\mathrm{g}=9.81 \mathrm{~m} \cdot \mathrm{s}^{-2}$ ) with a precision of $0.01 \mathrm{~m}$. During testing, the participants were instructed to place their hands on their hips, with their feet shoulder width apart, and adopt a flexed $\sim 90^{\circ}$ knee position for three seconds, followed by a maximal effort vertical jump. Take-off and landing were standardised to full knee and ankle extension on the same spot. Participants were instructed to maximise jump height and bend the knees after landing. Three trials were completed with a rest period of two minutes between each trial. The highest jump was used for the subsequent analysis.

In a short-course (i.e., $25 \mathrm{~m}$ ) pool, and using the crawl swim style, swimmers completed a warm-up of $50 \mathrm{~m}$, and after five minutes of rest they performed one maximal $200 \mathrm{~m}$ time trial. They began the test by jumping from an official platform at the edge of the swimming pool. A digital watch was used to measure the race time.

\section{Speed swimming training}

After 15 min of dynamic swimming warm-up exercise (i.e. lunge and stretch, forward bend, standing backbend, arm circles, etc.), the training, including three 120 min swimming sessions per week at 85$95 \%$ of maximal heart rate, was completed. A normal speed swim session involved $25 \mathrm{~m}$ laps using different swim styles and equipment (i.e. fins).

The Plyometric training (PT) was done two times per week for six weeks. After five min of warm-up (light jogging, run-ups, and stretching), participants completed four jump drills using maximal effort for each jump repetition. During the six-week training programme, the intensity (height of the boxes) and the volume increased progressively. (Table 2)

Table 2. Plyometric training program.

\begin{tabular}{c|c|c}
\hline Plyometric training weeks & Drill (sets x repetitions) & $\begin{array}{c}\text { Recovery time (micro } \\
\text { x macropause) }\end{array}$ \\
\hline \multirow{4}{*}{ First and second } & 20-cm drop jump $(2 \times 9)$ & $5 \times 60$ seconds \\
\cline { 2 - 3 } & 30-cm drop jump $(2 \times 9)$ & $5 \times 60$ seconds \\
\cline { 2 - 3 } & 40 -cm drop jump $(2 \times 9)$ & $5 \times 60$ seconds \\
\cline { 2 - 3 } & Long jump $(2 \times 9)$ & $10 \times 120$ seconds \\
\hline \multirow{5}{*}{ Third and fourth } & 30 -cm drop jump $(2 \times 10)$ & $5 \times 60$ seconds \\
\cline { 2 - 3 } & 40 -cm drop jump $(2 \times 10)$ & $5 \times 60$ seconds \\
\cline { 2 - 3 } & $50-c m$ drop jump $(2 \times 10)$ & $5 \times 60$ seconds \\
\cline { 2 - 3 } & Long jump $(2 \times 10)$ & $10 \times 120$ seconds \\
\hline \multirow{5}{*}{ Fifth and sixth } & 40 -cm drop jump $(2 \times 11)$ & $5 \times 60$ seconds \\
\cline { 2 - 3 } & 50 -cm drop jump $(2 \times 11)$ & $5 \times 60$ seconds \\
\cline { 2 - 3 } & 60 -cm drop jump $(2 \times 11)$ & $5 \times 60$ seconds \\
\cline { 2 - 3 } & Long jump $(2 \times 11)$ & $10 \times 120$ seconds \\
\hline
\end{tabular}

Two minutes of rest was allowed between sets and exercises, and five seconds between repetitions. The training was completed on a wooden floor, using adequate sport shoes, and correct technique was stressed to reduce the risk of injury. A coach to participant ratio of 1:2-3 supervised all training sessions. During training, all participants were verbally motivated. Qualitative assessment of mood-state was regularly performed to reduce the chances of overreaching symptoms. Each specific plyometric session replaced lasted $\sim 15$ min of the speed swimming training.

\section{Statistical analysis}

Results are presented as mean values \pm standard deviations. All data was first log-transformed to reduce bias arising from non-uniformity error. An analysis with Student t-test was used to evaluate equivalence of the general characteristics and dependent variables between groups before the intervention ( $p>0.01)$. To observe the effects of the intervention, post- and pre- time changes in the dependent variables were analysed using a two-way ANOVA test $(p<0.01)$. Absolute changes between groups were analysed with Student t-test $(p<0.01)$. All analyses were carried out using GraphPad Prism software (version 7.0, USA).

\section{RESULTS}

General characteristics showed no significant differences between both groups ( $p>0.01$ ) (Table 1). Also, at baseline, no differences were observed between the groups for variables of flexibility $(p=0.09)$, girth of the right thigh ( $p=0.10)$, girth of the left thigh ( $p=0.63)$, jumping $(p=0.47)$, and swimming time performance $(p=0.79)$. After six weeks of intervention, there was a significant improvement in just the PTG in the 200-m swimming time (PRE: $220 \pm 26.5$ sec; POST: 204.9 \pm 24.4 sec; $p<0.01$ ), sit-and-reach flexibility (PRE: $4.5 \pm 5.3 \mathrm{~cm}$; POST: $10.9 \pm 5.9$ $\mathrm{cm} ; \mathrm{p}<0.01$ ), and squat jump performance (PRE: $24.9 \pm 3.7 \mathrm{~cm}$; POST: $28.3 \pm 4.2 \mathrm{~cm} ; \mathrm{p}<0.01$ ). (Table 3 )

In the analysis of mean absolute changes ( $\triangle$ :Post-Pre) between groups, 200m swimming time was lower $(\triangle:-15.1 \pm 2.4 \mathrm{sec} ; \mathrm{p}<0.01)$, and sit-and-reach flexibility $(\Delta:-6.3 \pm 0.6 \mathrm{~cm} ; \mathrm{p}<0.01)$ and squat jump performance $(\triangle: 3.5 \pm 0.7 \mathrm{~cm} ; p<0.01)$ were higher for the PTG when compared to the CG (Table 3). No significant differences were observed in the girths of right and left thighs between both groups ( $p>0.01)$. In addition, Figure 1 shows that all subjects of the PTG increased flexibility in the sit-and-reach test and improved performance in the $200 \mathrm{~m}$ swimming race. For the squat jump height, an increase was observed in almost all subjects.

\section{DISCUSSION}

The main finding of this study showed that adding PT to a six-week traditional speed swimming training regime improves short-race swimming performance in recreationally-trained adult swimmers without causing changes in thigh girth. In addition, the PT did not cause musculoskeletal injury. Conversely, the swimmers from the CG, who just

Table 3. Effects of 6 weeks of either speed swimming (control group, $n=8$ ) or speed swimming combined with plyometric training (Plyometric group, $n=10$ ) on anthropometric, flexibility, jumping, and swimming performance in middle-distance swimmers.

\begin{tabular}{|c|c|c|c|c|c|c|c|}
\hline & & \multicolumn{3}{|c|}{ Control group } & \multicolumn{3}{|c|}{ Plyometric group } \\
\hline \multicolumn{2}{|c|}{ Variables } & Pre & Post & Post-Pre & Pre & Post & Post-Pre \\
\hline \multirow{2}{*}{ Tight girth (cm) } & Right tight girth $(\mathrm{cm})$ & $58.2 \pm 1.8$ & $58.5 \pm 1.9$ & $0.4(-0.1,0.9)$ & $60.3 \pm 3.0$ & $59.9 \pm 2.9$ & $-0.3(-0.9,0.3)$ \\
\hline & Left tight girth $(\mathrm{cm})$ & $59.2 \pm 2.3$ & $59.2 \pm 2.1$ & $-0.1(-0.7,0.6)$ & $59.8 \pm 3.0$ & $59.3 \pm 2.9$ & $0.5(-0.1,1.1)$ \\
\hline \multicolumn{2}{|c|}{ Squat jump (cm) } & $26.2 \pm 3.9$ & $26.9 \pm 3.9$ & $0.7(-0.7,2.1)$ & $24.9 \pm 3.7$ & $28.3 \pm 4.2+$ & $3.5(2.2,4.7) \neq$ \\
\hline \multicolumn{2}{|c|}{ Swimming performance (sec) } & $216 \pm 32.8$ & $216 \pm 27.3$ & $-0.9(-6.6,4.9)$ & $220 \pm 26.5$ & $204.9 \pm 24.4 \dagger$ & $-15.1(-20.2,-10.0) \neq$ \\
\hline
\end{tabular}




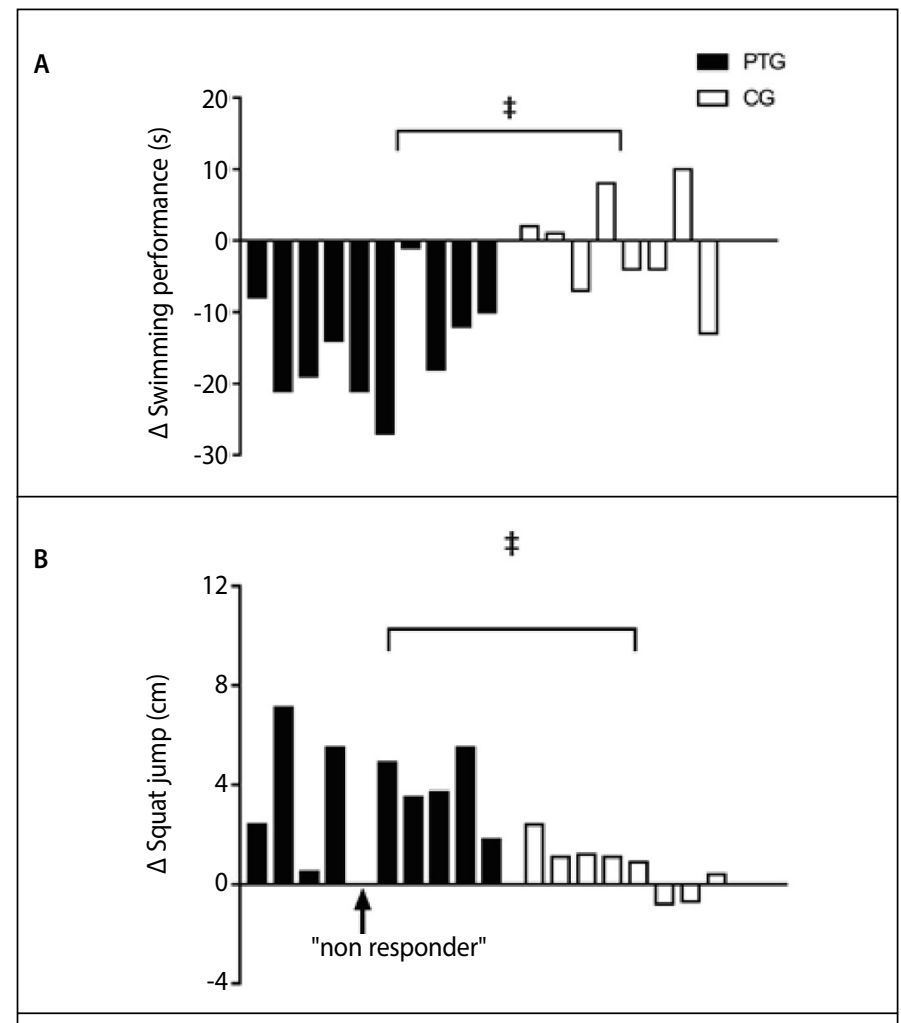

C

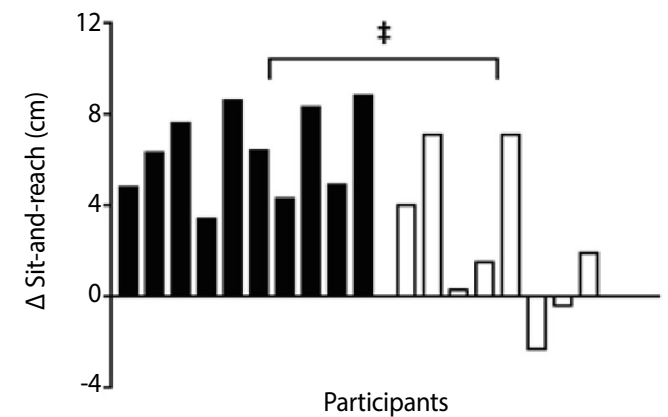

Figura 1. Absolute changes ( $\triangle$ : Post-Pre) between groups for 200m swimming time $(A)$, squat jump height (B) and sit-and-reach test $(C) ;(\neq=p<0.01)$.

carried out their usual speed swimming training, did not experience significant improvements in any variables.

In young athletes, PT has previously induced a significant increase in thickness of the quadriceps muscle, ${ }^{16}$ leg muscle volume, ${ }^{17}$ and mean thigh cross-sectional area. ${ }^{18}$ This confirms the anabolic effect observed in this type of training, mainly in young people. ${ }^{19}$ Before this study, the effects on thigh girth induced by PT in recreationally-trained adult swimmers were unknown. It is possible that the lack of change in thigh girth could be related to the short period of plyometric training used in this study. The evidence shows, that the time necessary to provoke whole and/or single fibre muscle hypertrophy by PT is at least eight weeks. ${ }^{20}$ Therefore, it is possible that six weeks of plyometric exercises in swimmers improves the power output, speed and jumping height due to nerve adaptations rather than to muscle hypertrophy.

Regarding flexibility, the current results are in line with previous findings, where PT induced an increase in this physical fitness trait. ${ }^{21}$ In swimmers, a higher level of flexibility can help them to swim faster. $^{8}$ Likewise, athletes with greater flexibility recover faster after high intensity exertion and reduce the risk of injury. ${ }^{22}$ Despite this, the increase in flexibility observed in this study is difficult to explain, as no further physiological measurements were obtained. Future studies may consider analysing the potential of PT on flexibility through neural-mediated adaptations, changes in the stiffness of the muscle-tendon complex and similar changes in the elastic behaviour of adjacent joint subcomponents. ${ }^{23}$ Given the relevance of the jump from the starting block and the flip turns on short-race swimming performance parameters such as start time, total time, dive force and distance underwater, sport scientists and coaches continue to look for the training mode that increases the performance of these parameters. Lyttle and Benjanuvatra (2005) have identified that in 50m, $100 \mathrm{~m}$ and $200 \mathrm{~m}$ swimming races, the jump from starting block represents approximately $30 \%, 15 \%$ and $7.5 \%$ of the total time registered, respectively. ${ }^{24}$ Recently, Morais et al. (2018) observed that start and flip turns represent one-third of the total time of $100 \mathrm{~m}$ swimming race. ${ }^{25}$ All of the above suggests that swimmers should spend a large part of the training session performing exercises to improve the performance of these movements, for example through the explosive leg workouts. It should be noted that lower-limb explosive strength may also increase the swimming distance per stroke and the strength of the kick, ${ }^{8}$ improving performance. An increase in lower body strength and power output improved the start time ${ }^{3}$ and flip turn push-off performance ${ }^{5}$ in sprint swimmers. In this regard, our study showed that a six-week PT increases squat jump height (and therefore leg jump power output) and improves performance in 200m swimming trials. Other studies have also found improvements in swimming performance after land-based PT programmes of similar duration and training content, showing that land-based (i.e., isoinertial) PT have a high transference into water-based (i.e., isokinetic) muscle actions. ${ }^{13,15}$ In fact, compared to water-based, land-based PT may induce greater improvements in explosive power in the lower limbs. ${ }^{26}$ In addition, a recent study showed that an improvement in jumping performance was accompanied by an improvement in swim time in competitive triathletes. ${ }^{27}$ Similarly, our results indicate that swimmers improved their swim time $(\sim 6.9 \%)$ concurrently with an increase in jumping performance $(\sim 14.1 \%)$. Therefore, it is possible that the improvement in the explosive jump force induced by plyometric training improved the strength of kick during swimming, in turn improving leg propulsion, and thus, swimming speed. ${ }^{28}$ Although participants were only recreationally-trained adult swimmers, significant improvements in swimming performance have been reported after nine weeks of PT in highly-trained swimmers (i.e., weekly swim volume up to $56 \mathrm{~km}$ ). ${ }^{29}$ Similarly, performance improvements between 7 and $41 \%$ in young moderately-trained swimmers have been reported after six and eight weeks of PT. ${ }^{13,14}$ Alternatively, no changes in mood-state participants no were shown. Therefore, our proposal of plyometric training is safe for adult swimmers to improve performance in a $200 \mathrm{~m}$ swimming race. For future studies, it would also be interesting to analyse the effects of taper strategies for swimmers, who usually incorporate high-intensity interval training, with the incorporation of high-intensity PT, as previous studies have shown promising findings. ${ }^{30}$ Finally, it is worth noting that this research intervention was performed with ten recreationally-trained adult male swimmers, with all the inherent limitations related to this experimental design (i.e., training level). Particularly, current results may not be applicable to a paediatric population, for whom the effects may depend on their maturation-related differences. ${ }^{12}$ Therefore, the current PT may be especially well suited for swimmers peaking (tapering) for competition. Future studies may also consider an analysis of the effects of current training programmes on other swimming distances and analysis of underwater flip turns 
in order to better understand the biomechanical factors underlying performance changes.

\section{CONCLUSION}

A short-term high-intensity plyometric training coupled with a speed swimming training programme for six weeks, improves jump height, flexibility, and 200-m swimming performance in recreationally-trained adult male swimmers.

AUTHORS' CONTRIBUTIONS: Each author made significant individual contributions to this manuscript. RCJ: carried out design of the work, experimental protocols, statistical analysis, interpretation of the data and writing; JFP: carried out the interpretation of the data; RRC: carried out the statistical analysis, interpretation of data and writing; MT: carried out the statistical analysis, interpretation of data and writing. All authors approved the final version of the manuscript

\section{REFERENCES}

1. Amaro NM, Morouço PG, Marques MC, Batalha N, Neiva H, Marinho DA. A systematic review on dry-land strength and conditioning training on swimming performance. Science \& Sports. 2019;34:e1-e14

2. Cossor J, Mason B. Swim start perfomances at the Sydney 2000 Olympic Games. In: XIXth International Symposium on Biomechanics in Sports, San Francisco. 2001:70-74.

3. West DJ, Owen NJ, Cunningham DJ, Cook CJ, Kilduff LP. Strength and power predictors of swimming starts in international sprint swimmers. J Strength Cond Res. 2011;25:950-955.

4. Lyttle AD, Blanksby BA, Elliott BC, Lloyd DG. Net forces during tethered simulation of underwater streamlined gliding and kicking techniques of the freestyle turn. J Sports Sci. 2000;18:801-807.

5. Jones JV, Pyne DB, Haff GG, Newton RU. Comparison of ballistic and strength training on swimming turn and dry-land leg extensor characteristics in elite swimmers. Int J Sports Sci Coach. 2018;13:262-269.

6. Andrade DC, Beltrán AR, Labarca-Valenzuela C, Manzo-Botarelli O, Trujillo E, Otero-Farias $P$, et al Effects of Plyometric Training on Explosive and Endurance Performance at Sea Level and at High Altitude. Front Physiol. 2018;9:1415.

7. Toussaint HM, Roos PE, Kolmogorov S. The determination of drag in front crawl swimming. J Biomech. 2004;37:1655-1663.

8. Willems T, Cornelis J, De Deurwaerder L, Roelandt F, De Mits S. The effect of ankle muscle strength and flexibility on dolphin kick performance in competitive swimmers. Hum Mov Sci. 2014:36:167-176

9. Wang YC, Zhang N. Effects of plyometric training on soccer players. Exp Ther Med. 2016;12:550-554.

10. Egan-Shuttler JD, Edmonds R, Eddy C, O'Neill V, Ives SJ. The effect of concurrent plyometric training versus submaximal aerobic cycling on rowing economy, peak power, and performance in male high school rowers. Sports Med Open. 2017;3:7.

11. Mazurek K, Zmijewski P, Makaruk H, Mroz A, Czajkowska A, Witek K, et al. Effects of short-term plyometric training on physical performance in male handball players. J Hum Kinet. 2018;63:137-148

12. Moran J, Sandercock GRH, Ramirez-Campillo R, Todd O, Collison J, Parry DA. Maturation-related effect of low-dose plyometric training on performance in youth hockey players. Pediatr Exerc Sci. 2017;29:194-202.

13. Bishop DC, Smith RJ, Smith MF, Rigby HE. Effect of plyometric training on swimming block start performance in adolescents. J Strength Cond Res. 2009;23:2137-2143

14. Potdevin FJ, Alberty ME, Chevutschi A, Pelayo P, Sidney MC. Effects of a 6-week plyometric training program on performances in pubescent swimmers. J Strength Cond Res. 2011;25:80-86.

15. Cossor JM, Blanksby BA, Elliott BC. The influence of plyometric training on the freestyle tumble turn. J Sci Med Sport. 1999;2:106-116.

16. Skurvydas A, Brazaitis M. Plyometric training does not affect central and peripheral muscle fatigue differently in prepubertal girls and boys. Pediatr Exerc Sci. 2010;22:547-556.
All authors declare no potential conflict of interest related to this article 